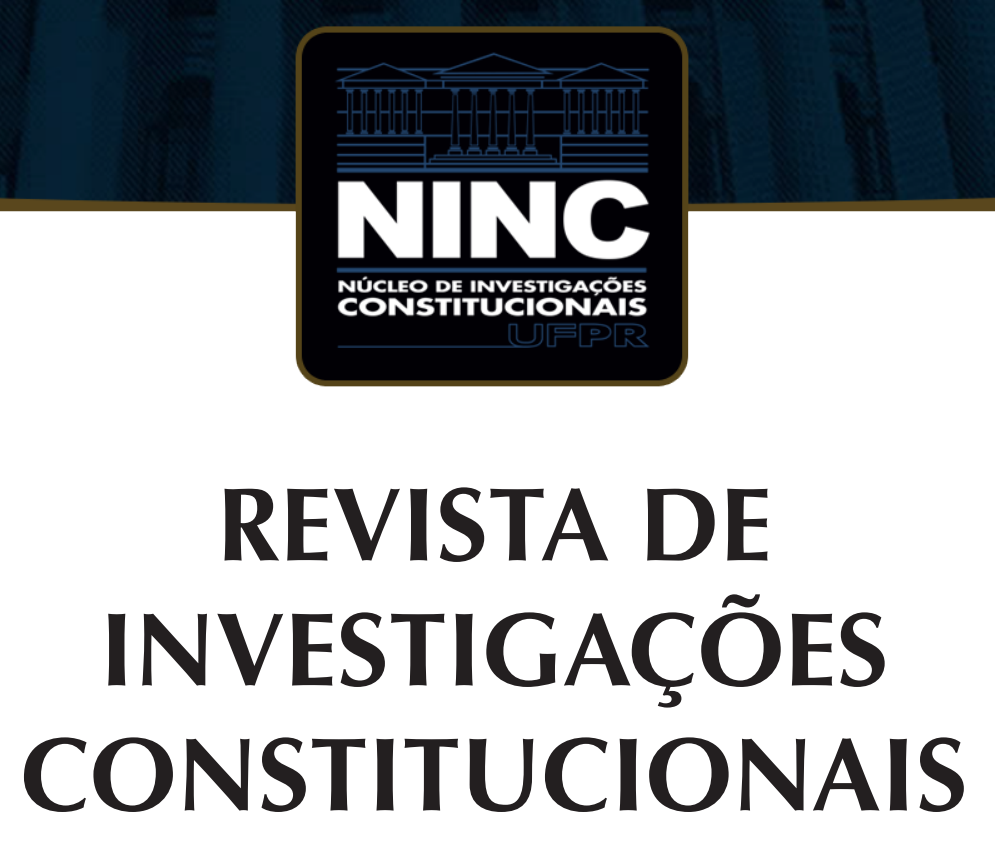

JOURNAL OF CONSTITUTIONAL RESEARCH

vol. 7 | n. 1 | janeiro/abril 2020 | ISSN 2359-5639 | Periodicidade quadrimestral Curitiba | Núcleo de Investigações Constitucionais da UFPR | www.ninc.com.br 


\title{
Constitutional Law around the globe: judicial review in the United States and the "writ of certiorari"
}

\section{Direito Constitutional ao redor do globo: o controle judicial de constitucionalidade nos Estados Unidos e o "writ of certiorari"}

\author{
LUIZ HENRIQUE DINIZ ARAÚJO I,* \\ ' Faculdade Boa Viagem/Devry (Recife, Pernambuco,Brasil) \\ luizdinizaraujo@hotmail.com \\ http://orcid.org/0000-0001-7682-0038 \\ Recebido/Received: 20.05 .2020 / May $20^{\text {th }}, 2020$ \\ Aprovado/Approved: 28.08 .2020 / August $28^{\text {th }}, 2020$
}

\section{Abstract}

This paper exploring the writ of certiorari in the United States Constitutional Law is the second of the series "Constitutional Law Around the Globe". This section of the series focuses on "Judicial Review and the Filters to Access Supreme and Constitutional Courts". The first paper in the row, published in the year 2019, analyzed the Constitutionality Priority Question (Question Prioritaire de Constitutionnalité - QPC) in France. In this second paper, we analyze how the U.S. Supreme Court picks cases from thousands that reach it every year and the strategies that the Court adopts to filter these cases. The paper focuses specifically on Rule 10, the "writ of certiorari" and their operation in practice.

Keywords: judicial review; U.S. Supreme Court; access filters; Rule 10; writ of certiorari.
Resumo

Este artigo, analisando o "writ of certiorari" no Direito Constitucional dos Estados Unidos, é o segundo da série "Direito Constitucional ao Redor do Globo". Esta parte da série tem por foco "O Controle Judicial de Constitucionalidade e Filtros de Acesso a Cortes Constitucionais e Supremas". O primeiro trabalho, publicado no ano de 2019, tratou da Questão Prioritária de Constitucionalidade na França (Question Prioritaire de Constitutionnalité - QPC). Neste segundo trabalho, analisa-se como a Suprema Corte dos Estados Unidos seleciona casos entre os milhares que Ihe chegam todos os anos, bem como as estratégidas que a Corte adota para filtrar esses casos. $O$ artigo tem por foco específico a Rule 10, o "writ of certiorari" e a sua utilização na prática constitucional norte-americana.

Palavras-chave: controle judicial de constitucionalidade; Suprema Corte dos Estados Unidos; filtros de acesso; Rule 10; writ of certiorari.

Como citar esse artigo/How to cite this article: ARAÚJO, Luiz Henrique Diniz. Constitutional Law around the globe: judicial review in the United States and the "writ of certiorari". Revista de Investigações Constitucionais, Curitiba, vol. 7, n. 1, p. 189-204, jan./abr. 2020. DOI: 10.5380/rinc.v7i1.73893.

* Professor da Faculdade Boa Viagem/Devry (Recife-PE, Brasil). Doutor pela Universidade Federal de Pernambuco (Recife-PE, Brasil). Mestre pela Universidade Federal de Pernambuco (Recife/PE, Brasil). Visiting Researcher na University of California, Berkeley (California, EUA). Estágio Pós-Doutoral na Université Paris 1 Panthéon-Sorbonne. Procurador Federal. Coordenador Nacional de Direito Processual Civil da Escola da Advocacia-Geral da União. Professor de Direito Constitucional e Direito Processual Civil da Escola da AGU. Coordenador da área Fazenda Pública da Escola Superior da Advocacia Ruy Antunes - ESA/PE. Membro do Grupo REC de Estudos Constitucionais. Membro da Associação Norte e Nordeste de Professores de Processo. E-mail: luizdinizaraujo@ hotmail.com. 


\section{CONTENTS}

1. Introduction; 2. Judicial review and the Supreme Court in the United States Constitutional Law;

3. The writ of certiorari; 3.1. A brief History; 3.2. Certiorari and Rule 10; 3.3. Some pros and cons of the certiorari; 4 . The criteria/strategies for the selection of cases in practice; $\mathbf{5}$. Proposals for reform; 6. Conclusion; 7. References.

\section{INTRODUCTION}

This paper exploring the writ of certiorari in the United States Constitutional Law is the second of a series named "Constitutional Law Around the Globe". This section of the series focuses on Judicial Review and the Filters to Access Supreme and Constitutional Courts. The first paper in the row, published in the year 2019, analyzed the Constitutionality Priority Question (Question Prioritaire de Constitutionnalité - QPC) in France. ${ }^{1}$

The intention of this chapter on filters to Constitutional and Supreme Courts is shed light on specifics of the systems under scrutiny, as well as their apex courts and how a case can be granted permission to be decided, in a time when judicial review is an important feature within many contemporary democracies.

This research is particularly fascinating in our times because the ways and filters to a case up to a Supreme or Constitutional Court can define the extent and shape of constitutional and fundamental rights in a specific jurisdiction. If in one hand the existence of filters is necessary in order to keep away from supreme courts trivial cases, on the other hand they cannot be so restrictive that keep relevant constitutional cases away from the courts of last resort.

From the $20^{\text {th }}$ century on, courts (specially Supreme and Constitutional Courts) have gained power in deciding constitutional and even political cases, such as in South Korea, South Africa, New Zealand, U. S., the European Court of Justice and the European Court of Human Rights. ${ }^{2}$

In recent decades, also Latin America has experienced the empowerment of courts. Within this broader context, Constitutional Courts have been adopted (Chile in 1981; Colombia in 1991; Peru in 1993; Equador in 1996; Bolívia in 1998) or have gained power (Brazil in 1988; Costa Rica in 1989). As a consequence, judicialization of constitutional fundamental rights and judicial review have been in rise. ${ }^{3}$

\footnotetext{
ARAÚJO, Luiz Henrique Diniz. Filtros de acesso às Cortes Constitucionais: a Questão Prioritária de Constitucionalidade e os filtros de acesso ao Conselho Constitucional Francês. Revista de Investigações Constitucionais, Curitiba, vol. 6, n. 2, p. 405-422, maio/ago. 2019.

2 KAPISZEWSKI, Diana; SILVERSTEIN, Gordon; KAGAN, Robert A. Consequential Courts. Judicial Roles in Global Perspective. Cambridge: Cambridge University Press, 2013, p. 1.

3 COUSO, Javier A.; HUNEEUS, Alexandra; SIEDER, Rachel. Cultures of Legality. Judicialization and Political Activism in Latin America. Cambridge: Cambridge University Press, 2010, p. 142.
} 
In Brazil, there is a certain consensus among scholars, attorneys, justices, judges and lawyers in general that the growth in importance and number of cases in Brazilian Supreme Court demands reforms in order to block "unimportant" or trivial constitutional matters from reaching the High Court. One of these proposals is to rebuild the filters to access the Highest Cout in the diffuse model of Brazilian judicial review ${ }^{4}$.

In this broad context, Brazilian Supreme Court (and also the lower courts and judges) has been playing a very important role in the democratic process. This has lead to many important decisions involving gay marriage ${ }_{,}^{5}$ abortion, ${ }^{6}$ assisted suicide, the reform of the social security system, the reform of the political system, all sorts of environmental cases, tax matters, educational matters, ${ }^{7}$ criminal law matters, among others.

In this series, our aim is to proceed with coming papers exploring filters in other constitutional systems, culminating with the analysis of the filters in Brazilian Constitutional Law in comparative perspective with the other systems composing the series.

In this specific paper, we will be analyzing how the U.S. Supreme Court picks cases from thousands that reach it every year and the strategies that the Court adopts to filter these cases. It will be demonstrated how the relation "number of cases chosen/ number of cases filed" has historicaly decreased over the decades as a result of several reforms that culminated wiht Rule 10 in 1988. This Rule sets some standards but in practical grounds gives broad discretion for Supreme Court Justices to decide which cases they consider worth a decision or not. In this context the writ of certiorari, major focus of this paper, is a central device.

The problem under scrutiny is the issue of filters to access Supreme and Constitutional Courts. In one hand scholars argue that these filters should not be so strict that block or make too difficult a decision in a case; on the other hand, they cannot be excessively loose in order to vulgarize the decisions of apex courts or even allow the size of their docket to an almost unmanageable point.

\footnotetext{
4 The model of Brazilian judicial review adopted by the Constitution-1988 combines the United States model (diffuse model) and the European model (abstract model). As a result, in Brazilian system, every judge is entitled to declare a statute unconstitutional in the case to be decided. These decisions are appealable to lower courts and in last resort to the Supreme Court. In addition to that, there are direct actions (or direct constitutional lawsuits) that are decided exclusively by the Supreme Court in an abstract fashion (with general effects). A wide range of public and private actors is entitled to file these lawsuits directly into the Supreme Court.on the influences of Brazilian judicial review system, see: JORDÃO, Eduardo. Globalization and convergence in judicial review: what can we learn from the case of Brazil? A\&C - Revista de Direito Administrativo \& Constitucional, Belo Horizonte, ano 17, n. 69, p. 23-31, jul./set. 2017.

5 ARAÚJO, Luiz Fernando Diniz. O ativismo judicial e constrangimentos a posteriori. Revista de Investigações Constitucionais, Curitiba, vol. 5, n. 1, p. 129-150, jan./abr. 2018.

6 MACHADO, Marta Rodriguez de Assis; COOK, Rebecca J. Constitutionalizing abortion in Brazil. Revista de Investigações Constitucionais, Curitiba, vol. 5, n. 3, p. 185-231, set./dez. 2018.

7 LOURENÇO, Cristina Sílvia Alves; GUEDES, Maurício Sullivan Balhe. O STF e o ensino religioso em escolas públicas: pluralismo educacional, laicidade estatal e autonomia individual. Revista de Investigações Constitucionais, Curitiba, vol. 4, n. 3. p. 145-165, set./dez. 2017.
} 
The aim of the section Judicial Review of the Series Constitutional Law Around the Globe is to analyse filters in different constitutional systems in order to identify some of its vices and virtues and, in the end, produce a final paper approaching the theme of the filters to Supreme and Constitutional courts in a comparative perspective.

The hypothesis of the series is that the filters of access are important devices to be used aiming to balance the access to courts of last resort with the goal of permiting constitutional and supreme courts to decide on constitutionally important matters in a number that allows a manageable docket size, in order to preserve the quality of decisions and the system integrity.

The methodology used is consultation of references.

\section{JUDICIAL REVIEW AND THE SUPREME COURT IN THE UNITED STATES CONSTITUTIONAL LAW}

Differently from many other north american legal traditions, that were strongly influenced by the British Law, judicial review in the United States was a creation with little antecedents in Britain. It is broadly known that judicial review is not present in the U.S. constitutional text and it is commonplace that it was created by Chief Justice John Marshall of the United States Supreme Court (or simply SCOTUS) in the year 1803, in Marbury v. Madison. ${ }^{8}$ Nevertheless, judicial review has a much more remote origin. In the U.S., Courts exercised judicial review even before the enactment of the U.S. Constitution in the end of the XVIII Century.

In well-known cases and others already forgotten, over the last two certuries courts in the US have declared federal and state statutes constitutional, agencies acts, Presidential acts, as well as competences of state and local governments. Thus, over the centuries, judicial review has deferred to the U.S. Constitution a more practical than merely rethorical force. ${ }^{9}$

In the U.S. Constitutional Law, there were four potential candidates to the title of final arbiter of the U.S. Constitution: Congress, the President, States and Courts. Due to historical reasons, each of the three first options was rejected, making courts final interpreters of the Constitution. ${ }^{10}$

In U.S. Law, every state or federal court has the authority to decide on constitutional matters. However, all those decisions are subject to ultimate review by the

\footnotetext{
8 CASAGRANDE, Cássio Luís; TIBÚRCIO, Dalton Robert. Marbury v. Madison: uma decisão política de manter a Corte fora da política. A\&C - Revista de Direito Administrativo \& Constitucional, Belo Horizonte, ano 19, n. 76, p. 199-224, abr./jun. 2019.

9 FARBER, Daniel; SHERRY, Suzanna. Judgement calls: politics and principle in Constitutional Law. New York: Oxford University Press, 2008, p. 12.

10 FARBER, Daniel; SHERRY, Suzanna. Judgement calls: politics and principle in Constitutional Law. New York: Oxford University Press, 2008, p. 13.
} 
Supreme Court of the United States, composed by nine justices. The President, Congress, state legislatures, governors, state courts, state and federal administrative agencies, ${ }^{11}$ public officials, and all ordinary citizens are subject to the authority of the Supreme Court's decisions. ${ }^{12}$

Almost all cases the Supreme Court is to decide must first of all be granted a writ of certiorari by four of the nine justices, as it will be explained next.

\section{THE WRIT OF CERTIORARI}

Explained shortly, the way for a case up to the United States Supreme Court starts after it is decided in a Court of Appeals, a State Supreme court or other court of last resort. The losing party has to file a petition for a writ of certiorari to the Supreme Court ("cert petition").

The respondent, then, has the right to file a brief in opposition to the writ, but she may simply waive her right to file a brief and wait to see if the Court requests one by means of a "call for response" or simply "CFR". If the respondent files an opposition brief, the petitioner has the right to file a reply brief before the Court considers whether or not to grant certiorari. ${ }^{13}$

The Court may also invite the Department of Justice, through the Solicitor General of the United States (the "SG"), to file a brief analyzing the petition, a process named as a "call for the views of the SG," or "CVSG."14

This is a short explanation of the procedure that can open the Supreme Court doors to decide a case. It has not always been like this, though.

\subsection{A brief History}

During the first century since its foundation, the United States Supreme Court did not have the power to choose the cases it would decide. Actually, the Judiciary Act (1789) enacted by Congress established that the Supreme Court would have appellate jurisdiction on several decisions from the federal circuit courts and state courts

11 ALBERT, Richard; NIKOLAYEVA, Anna. Judicial review of administrative action in the United States. A\&C Revista de Direito Administrativo \& Constitucional, Belo Horizonte, ano 17, n. 70, p. 13-23, out./dez. 2017.

12 FEINMAN, Jay M. Law 101. $5^{\text {th }}$ edition. New York: Oxford University Press, 2018, p. 24-25

13 THOMPSON, David C.; WACHTELL, Melanie F. An Empirical Analysis of Supreme Court Certiorari Petition Procedures: The Call for Response and the Call for the Views of the Solicitor General, Geo. Mason L. Rev., Arlington, vol. 16, p. 237-302, 2009, p. 242-243.

14 THOMPSON, David C.; WACHTELL, Melanie F. An Empirical Analysis of Supreme Court Certiorari Petition Procedures: The Call for Response and the Call for the Views of the Solicitor General, Geo. Mason L. Rev., Arlington, vol. 16, p. 237-302, 2009, p 242-243. 
decisions that defeated rights set up by the appellant under the Constitution, laws or treaties of the United States ${ }^{15}$.

In 1891, Congress passed the Circuit Courts of Appeals Act, a response to an unmanageable increase of the Court's caseload. At the beginning of the 1890 Term, the justices had a rollup of 1,800 cases. According to the Circuit Courts of Appeals Act, a new set of federal courts of appeals was created (the circuit courts of appeals). These circuit courts had appellate jurisdiction on various classes of decisions previously directly appealable to the Supreme Court. ${ }^{16}$

Some of the circuit courts' decisions were, in turn, appealable to the Supreme Court. However, other classes of cases were decided by the circuit courts of appeals in a definitive way, except if the Supreme Court required by certiorari or otherwise the power for its review. This was the beginning for a deep shift in the Supreme Court's role.

In the decades to come, there was a trend towards reducing the Courts's mandatory jurisdiction. The justices themselves demanded and some even lobbied in favor of greater discretionary power.

In 1925, with the passage of the "Judges' Bill", an old dream of then Chief Justice Taft, became true. All decisions by the federal appellate courts would from then on be final and only reviewable by certiorari. The Court's power to discretionarily set its own agenda turned it from a neutral arbiter and interpreter of policy into an active participant in policy making. Finally, the Judiciary Act enacted by Congress in 1988 virtually eliminated the Court's mandatory appellate jurisdiction. ${ }^{17}$

Nowadays, the Supreme Court's appellate jurisdiction is almost completely discretionary through the writ of certiorari. The Court's mandatory appellate jurisdiction is established only on final judgments by three-judge district courts, required by statute for a few classes of cases, and final judgments by single-judge district courts in certain antitrust decisions.

The vast majority of the cases the Court hears come from its certiorari docket and the Court only hears a tiny minority of them. From approximately $7,000-8,000$ certiorari petitions filed every year, the Court grants review to as much as about 80-90 each year. ${ }^{18}$ How come? What are the rules and criteria regulating the grant of a certiorari?

\footnotetext{
15 EPPS, Daniel; ORTMAN, William. The Lottery Docket. Michigan Law Review. Ann Arbor/MI, vol. 116, p. 705757, march 2018, p. 710.

16 EPPS, Daniel; ORTMAN, William. The Lottery Docket. Michigan Law Review. Ann Arbor/MI, vol. 116, p. 705757, march 2018, p. 710.

17 EPPS, Daniel; ORTMAN, William. The Lottery Docket. Michigan Law Review. Ann Arbor/MI, vol. 116, p. 705757, march 2018, p. 712.

18 EPPS, Daniel; ORTMAN, William. The Lottery Docket. Michigan Law Review. Ann Arbor/MI, vol. 116, p. 705757, march 2018, p. 713.
} 


\subsection{Certiorari and Rule $\mathbf{1 0}$}

Today, Rule 10 of the U.S. Supreme Court establishes broad parameters for granting a writ of certiorari. It states that

Review on a writ of certiorari is not a matter of right, but of judicial discretion. A petition for a writ of certiorari will be granted only for compelling reasons. The following, although neither controlling nor fully measuring the Court's discretion, indicate the character of the reasons the Court considers:

(a) a United States court of appeals has entered a decision in conflict with the decision of another United States court of appeals on the same important matter; has decided an important federal question in a way that conflicts with a decision by a state court of last resort; or has so far departed from the accepted and usual course of judicial proceedings, or sanctioned such a departure by a lower court, as to call for an exercise of this Court's supervisory power;

(b) a state court of last resort has decided an important federal question in a way that conflicts with the decision of another state court of last resort or of a United States court of appeals;

(c) a state court or a United States court of appeals has decided an important question of federal law that has not been, but should be, settled by this Court, or has decided an important federal question in a way that conflicts with relevant decisions of this Court.

A petition for a writ of certiorari is rarely granted when the asserted error consists of erroneous factual findings or the misapplication of a properly stated rule of law. ${ }^{19}$

Scholars have argued that these rules are insufficiently precise. In the end, the broad discretion of the Supreme Court power in granting certiorari strikes one's attention..$^{20}$ The result is that while the number of cases decided by the federal courts and coming before the Supreme Court grew steadily since 1925, the number of cases the Court decides has gone in the opposite direction.

Actually, the Supreme Court's plenary docket in 2004 was half the size it was in 1986 whereas the dockets of the federal circuit courts have increased by $82.4 \%$ during

19 Available at https://law.justia.com/codes/us/1997/title28/app/rulesofth/rule10/. Retrieved May 4, 2020.

20 MORAWA, Alexander H. E. Ceriorari and the Political Judge: Discretionary Case Selection by the United States Supreme Court and the European Court of Human Rights Compared. The University of Tasmania Law Review, Hobart, Tasmania, vol. 33, n. 2, p. 222-234, 2014, p. 228. 
the same period. During the 1947 Term, the Supreme Court decided 143 cases by written, signed opinion (about 11 percent of its docket); in 1967, it decided 155 cases by written, signed opinion (about 4 percent of its docket); in 1987, the Court decided 151 cases by written, signed opinion (about 3 percent of its docket); in 2007, the Court decided only 72 cases by written, signed opinion (less than 1 percent of its docket). ${ }^{21}$

Arguing a case before the Supreme Court of the US ends up being one of the most prestigious accomplishments in the American Bar. The chance to argue before the SCOTUS opens doors to high-paying opportunities and litigating issues of national importance 22 , so difficult it is to get a case accepted to be decided.

\subsection{Some pros and cons of the certiorari}

Quite controversial among scholars and lawyers, the certiorari has its defendants and contendors.

Its defendants list as advantages of the certiorari: (i) it is easier for the Supreme Court to change its interpretation of the Constitution; (ii) the Court can spend time on matters that are supposedly very important in order to receive a decision; (iii) the Supreme Court is allowed to intervene selectively. As a clear result, certiorari has a decisive role in shaping U.S. substantive constitutional law ${ }^{23}$. Some scholars argue that the Supreme Court's power to set its agenda may be even more important the substance of its decisions. ${ }^{24}$

On the other hand, important scholars and lawyers disagree from the core argument that certiorari allows the court to pick only important cases. ${ }^{25}$ This is based on the idea that the legal system would be better off if the Supreme Court decided some ordinary legal questions resolved by lower courts routinely. This would have the advantages of (i) keeping justices informed about statutes, regulations and even how the courts of appeal and state courts' decisions operate on practical grounds; (ii) constraining lower courts on these "unimportant matters", because a Supreme Court review

\footnotetext{
21 GEORGE, Tracey E.; GUTHRIE, Chris. Remaking the United States Supreme Court in the Courts' of Appeals Image. Duke Law Journal, Durham/NC, vol. 58, n. 7, Special Symposium Issue: Measuring Judges and Justice, p. 1439-1475, april 2009, p. 1440-1441.

22 TANG, Aaron. The Ethics of Opposing Certiorari Before the Supreme Court. Harvard Journal of Law and Public Policy, Cambridge/MA, vol. 35, n. 3, p. 933-990, summer 2012, p. 940.

23 HARTNETT, Edward A. Questioning Certiorari: Some Reflections Seventy-Five Years after the Judges' Bill Source. Columbia Law Review, New York, vol. 100, n. 7, p. 1643-1738, nov. 2000, p. 1730-1731.

24 HARTNETT, Edward A. Questioning Certiorari: Some Reflections Seventy-Five Years after the Judges' Bill Source. Columbia Law Review, New York, vol. 100, n. 7, p. 1643, nov. 2000, 1738.

25 EPPS, Daniel; ORTMAN, William. The Lottery Docket. Michigan Law Review. Ann Arbor/MI, vol. 116, p. 705757, march 2018, p. 707.
} 
would be possible at least theoratically. It would as a consequence make lower courts more accountable for their own decisions. ${ }^{26}$

There are some other questions raised critically: how can cert power be reconciled with the classic justification for judicial review? How can a court with such power claim to be exercising judgment rather than will, and is such a power consistent with the rule of law? Can this power be justified as a form of administrative rather than judicial power? ${ }^{27}$

\section{THE CRITERIA/STRATEGIES FOR THE SELECTION OF CASES IN PRACTICE}

Is has been mentioned that today the Supreme Court of the United States has nearly boundless power to decide which cases it will hear. Since 1988, the Court has almost a limitless power to set its own agenda and a decrease in number of cases granted certiorari is verified, despite promises by the time of the enactement of Rule 10 that certiorari in constitutional cases only would be denied when the decision aimed to be reviewed was clearly correct.

Certainly, the Court has the discretion of selecting the cases it considers worth deciding. But, in practice, can be found in the SCOTUS case-load patterns that drive the grant of certiorari?

In order to reduce the thousands of certiorari petitions to the small number of granted cases the Court has developed various internal mechanisms. One of them is institutional. Since 1972, many justices have combined the efforts of their chambers in the "cert pool". Petitions divided among the chambers of participating justices are distributed to law clerks in order to prepare a memorandum for each petition with a recommendation to be shared with the other justices and their clerks. Created at the suggestion of Justice Powell, today seven of the nine judges participate in the "cert pool".

Another mechanism is substantive. Instead of an argument of all-things-considered about a case, criteria have been identified in order to justify a grant of certiorari and they are summarized on Rule $10 .{ }^{28}$ However, how do that Rule`s broad terms operate in practical grounds?

Following the initial review processes in the cert pool, petitions are set for discussion in conference. A first step after that is the creation by the Chief Justice of a "discuss list" that is complemented by a so-called "dead list". Both lists form the basis for the

26 EPPS, Daniel; ORTMAN, William. The Lottery Docket. Michigan Law Review. Ann Arbor/MI, vol. 116, p. 705757, march 2018, p. 707.

27 HARTNETT, Edward A. Questioning Certiorari: Some Reflections Seventy-Five Years after the Judges' Bill Source. Columbia Law Review, New York, vol. 100, n. 7, p. 1643-1738, nov. 2000, p. 1713.

28 EPPS, Daniel; ORTMAN, William. The Lottery Docket. Michigan Law Review. Ann Arbor/MI, vol. 116, p. 705757, march 2018, p. 713-4. 
"Friday Conference", when all justices will discuss matters submitted for review. Cases that are not part of the lists are not voted on.

Justices then present their views on the "cert-worthiness" in order of seniority. The "vote of four" allows a minority of four justices out of the nine to select cases to be further decided by the Supreme Court. The vote is generally not publicized. Because of that, reasons why cert is denied are not available to the public. ${ }^{29}$

Although it is not usual, justices are allowed to dissent from the denial of certiorari or to make statements respecting it. The dissenting opinions are a kind of dicta. They show that the denial was hard fought, besides playing the role of an invitation for litigants that are thus aware that if circunstances materially change, petitioners can try to bring the issue again to the Supreme Court. ${ }^{30}$

It is no easy task to predict which cases will be granted certiorari. The court's procedure for petition selection is not clearly understood. Litigants and analysts try to find signals that can shed some light on the matter, for instance: (i) if the Court calls for a response, does it mean that the case is more likely to be heard? (ii) what if the Court asks for the Solicitor General's views? ${ }^{31}$

Actually, it can be said that the major criteria for selection of cases is divide in lower courts ${ }^{32}$. Thus, if two courts of appeals decided the same issue differently, the grant of certiorari is more likely. In these cases, the Supreme Court aims geographic uniformity in federal law. ${ }^{33}$ It is a quest for universality in law that seems central to the Supreme Court.

The Court's emphasis on splits is often attributed to the important role of law clerks. Clerks are normally inexperienced young lawyers who are usually only a year or two out of law school and, as such, need objective criteria. Circuit splits is quite a verifiable one. The creation of the cert pool has caused an increase in the importance of circuit conflit, a tendency that spread to nonpool clerks. ${ }^{34}$

\footnotetext{
29 MORAWA, Alexander H. E. Ceriorari and the Political Judge: Discretionary Case Selection by the United States Supreme Court and the European Court of Human Rights Compared. The University of Tasmania Law Review, Hobart, Tasmania, vol. 33, n. 2, p. 222-234, 2014, P 226-227.

30 MORAWA, Alexander H. E. Ceriorari and the Political Judge: Discretionary Case Selection by the United States Supreme Court and the European Court of Human Rights Compared. The University of Tasmania Law Review, Hobart, Tasmania, vol. 33, n. 2, p. 222-234, 2014, p. 227-228.

31 THOMPSON, David C.; WACHTELL, Melanie F. An Empirical Analysis of Supreme Court Certiorari Petition Procedures: The Call for Response and the Call for the Views of the Solicitor General, Geo. Mason L. Rev., Arlington, vol. 16, p. 237-302, 2009, p 240.

32 EPPS, Daniel; ORTMAN, William. The Lottery Docket. Michigan Law Review. Ann Arbor/MI, vol. 116, p. 705757, march 2018, p. 708.

33 NARECHENIA, Tejas N. Certiorari, Universality, and a Patent Puzzle. Michigan Law Review, Ann Arbor, vol. 116, p. 1345-1407, june 2018, p. 1348.

34 EPPS, Daniel; ORTMAN, William. The Lottery Docket. Michigan Law Review. Ann Arbor/MI, vol. 116, p. 705757, march 2018, p. 715.
} 
The presence of the United States government as petitioner or amicus seem to play a relevant role, too. ${ }^{35}$ Another important factor is the compliance by the federal courts to the Supreme Court decisions. ${ }^{36}$ Other scholars argue that the outcome-prediction also plays an importante role. They mean that justices follow an outcome-prediction strategy, voting to grant certiorari for cases they expect to win and denying cert for cases they expect to lose in the merits. ${ }^{37}$ On the other hand, the Court will almost never grant plenary review in a case without a response on file. ${ }^{38}$

The participation of the Solicitor General or other amicus briefs is also relevant. SCOTUS grants more than half of the petitions filed by the solicitor general, whereas only $3 \%$ for other petitions in paid cases. The presence (and quantity) of amicus briefs can indicate that an issue is important..$^{39}$

In contrast, petitions seeking merely "error correction" seldom receive a cert grant, despite Rule 10 states that the Supreme Court should take into consideration when evaluating certiorari petition if the lower cout decision contradicts a Supreme Court precedent. ${ }^{40}$ Thus, such use of certiorari is really rare and only granted when the Court considers the need to correct egregious errors. ${ }^{41}$ According to Rule 10, a "[a] petition for a writ of certiorari is rarely granted when the asserted error consists of erroneous factual findings or the misapplication of a properly stated rule of law".

This big picture, however, oversees the fact that certiorari standards vary considerably depending on the justice. Records show that different justices may consider relevant different aspects to take into consideration when voting on certiorari issues. This variation may depend on the conception the justice has on the Court and/or underlying judicial philosophy. ${ }^{42}$

\footnotetext{
35 SCOTT, Kevin M. Shaping the Supreme Court's Federal Certiorari Docket. Justice System Journal, Williamsburg, vol. 27:2, p. 191-207, 2006, p. 192.

36 SCOTT, Kevin M. Shaping the Supreme Court's Federal Certiorari Docket. Justice System Journal, Williamsburg, vol. 27:2, p. 191-207, 2006, p. 194.

37 BRENNER, Saul; WHITMEYER, Joseph M.; Harold J. Spaeth. The Outcome-Prediction Strategy in Cases Denied Certiorari by the U.S. Supreme Court. Public Choice, Berlin, vol. 130, n. 1/2, p. 225-237, jan. 2007, p. 225226.

38 THOMPSON, David C.; WACHTELL, Melanie F. An Empirical Analysis of Supreme Court Certiorari Petition Procedures: The Call for Response and the Call for the Views of the Solicitor General, Geo. Mason L. Rev., Arlington, vol. 16, p. 237-302, 2009, p 240.

39 EPPS, Daniel; ORTMAN, William. The Lottery Docket. Michigan Law Review. Ann Arbor/MI, vol. 116, p. 705757, march 2018, p. 715.

40 EPPS, Daniel; ORTMAN, William. The Lottery Docket. Michigan Law Review. Ann Arbor/MI, vol. 116, p. 705757, march 2018, p. 716.

41 EPPS, Daniel; ORTMAN, William. The Lottery Docket. Michigan Law Review. Ann Arbor/MI, vol. 116, p. 705757, march 2018, p. 716-717.

42 EPPS, Daniel; ORTMAN, William. The Lottery Docket. Michigan Law Review. Ann Arbor/MI, vol. 116, p. 705757, march 2018, p. 716-717.
} 
Some scholars argue that the considerable variation in the certiorari docket is not influenced by the ideological distance between the Supreme Court and the lower courts, nor by the internal division within the lower courts. They argue that the justices' preferences appear to play the crucial role in determining the size of the Court's docket. $^{43}$

From each individual justice standpoint, scholars have identified two strategies: (i) the "error correction strategy" - a justice who intends to reverse the decision of the lower court probably will vote to grant certiorari, whereas a justice who is satisfied with the lower court decision will probably vote to deny certiorari; (ii) the "outcome prediction strategy" - arguing that justices who want to affirm the decision of the lower court are more likely to vote to grant certiorari when they will likely win at the final vote. ${ }^{44}$

Certainly, Rule 10 terms are broad and this gives justices a good share of discretion when evaluating certiorari matters. However, there has been a growing perception among justices over time that many cases decided by the Supreme Court actually did not deserve to be heard. They should just end at the appeal level. Over time, there has been a claim that a decision by the Supreme Court should happen when an overarching motive is present, stressing its power to rule on issues of large legal or policital significance and to supervise the federal courts. This would assert it as an actual constitutional court.

\section{PROPOSALS FOR REFORM}

Proposals to reform the certiorari have proliferated in recent years, such as: (i) the creation of a "certiorari division" composed of non-Supreme Court judges to select cases for the Court's docket; (ii) bring back the "certification" process, whereby federal circuit courts could certify legal questions to the Supreme Court; (iii) some urge Congress to redesign the Supreme Court to make it work more like the U.S. courts of appeals, with more justices, decisions heard by panels, and an "en banc" procedure ${ }^{45}$; (iv) add senior lawyers to the Court's staff to assist the justices and their clerks in selecting cases $^{46}$.

There is also another suggestion of reform that goes in a direction other than improving the process of selecting "important" cases. This proposal, named "the lottery

\footnotetext{
43 SCOTT, Kevin M. Shaping the Supreme Court's Federal Certiorari Docket. Justice System Journal, Williamsburg, vol. 27:2, p. 191-207, 2006, p. 191.

44 BRENNER, Saul. Granting certiorari by the united states supreme court: An overview of the social science studies. Law Library Journal, Chicago, vol. 92, n. 2, p. 193-202, 2000, p. 196-197.

45 GEORGE, Tracey E.; GUTHRIE, Chris. Remaking the United States Supreme Court in the Courts' of Appeals Image. Duke Law Journal, Durham/NC, vol. 58, n. 7, Special Symposium Issue: Measuring Judges and Justice, p. 1439-1475, april 2009, p. 1442.

46 EPPS, Daniel; ORTMAN, William. The Lottery Docket. Michigan Law Review. Ann Arbor/MI, vol. 116, p. 705757, march 2018, p. 729-730.
} 
docket", intends to supplement the Supreme Court's docket by giving it jurisdiction over a new set of cases to be selected from the final decisions of circuit courts and entered into the court. The appellant and appellees would have the opportunity to file their briefs and the Supreme Court would be obliged to rule, just like a circuit court ${ }^{47}$.

The benefit of the supplementation of the Court's certiorari with a lottery docket would be, according to the proposal: (i) informational - the Supreme Court would be exposed to cases that would never pass the certiorari; (ii) greater accountability - in theory, every case decided by circuit courts would be candidates to be reviewed by the Supreme Court; (iii) bring important cases before the Court that never would pass the certiorari ${ }^{48}$.

\section{CONCLUSION}

As it was asserted in the introduction of this paper, this text is part of a series of papers that analyzes Constitutional and Supreme courts around the globe specially focusing on the filters and procedures raised in order to allow (or rather impede) a case to reach the apex courts of a legal system.

Following this path, this is the second paper of the series and sheds light on the writ of certiorari of the United States of America. This paper was preceded by another work that explores the filters to the Constitutionality Priority Question in the French Constitutional System. The next paper in the row will focus on the Canadian System for selecting cases to be decided by Canada Supreme Court. A final paper will compare most important issues among the systems under scrutiny.

In this perspective, this paper has demonstrated that the number of cases that receive a decision by the Supreme Court of the United States has decreased over the decades due to a set of reforms over time that culminated on Rule 10 of the Supreme Court.

According to this Rule, the vast majority of cases that will be decided by the SCOTUS must necessarily receive a grant of certiorari following some broad directives. It turns out that in practice a tiny small number of cases ends up receiving a decision after a quite discretionary and tight selection.

There appears to be a relative agreement as to what factors influence the justices' votes to grant or deny certiorari to each case. ${ }^{49}$ In practice, Rule 10 gives the Court a broad discretion in selecting cases to a point that scholars and lawyers permanently

47 EPPS, Daniel; ORTMAN, William. The Lottery Docket. Michigan Law Review. Ann Arbor/MI, vol. 116, p. 705757, march 2018, p. 731-732.

48 EPPS, Daniel; ORTMAN, William. The Lottery Docket. Michigan Law Review. Ann Arbor/MI, vol. 116, p. 705757, march 2018, p. 735-736.

49 SCOTT, Kevin M. Shaping the Supreme Court's Federal Certiorari Docket. Justice System Journal, Williamsburg, vol. 27:2, p. 191-207, 2006, p. 201. 
struggle to find out what criteria are really important for the court in order to give a positive opinion in granting certiorari, such as: the "cert pool"; the "vote of four"; divide in lower courts; the presence of the United States government as petitioner or amicus; the participation of the Solicitor General or other amicus briefs.

In contrast, petitions seeking merely "error correction" seldom receive a cert grant, despite Rule 10 states that the Supreme Court should take into consideration when evaluating certiorari petition if the lower court decision contradicts a Supreme Court precedent. ${ }^{50}$ Thus, such use of certiorari is really rare and only granted when the Court considers the need to correct egregious errors. ${ }^{51}$

This big picture, however, oversees the fact that certiorari standards vary considerably depending on the justice. Records show that different justices may consider relevant different aspects when voting on certiorari issues. This variation may depend on the conception the justice has on the Court and/or underlying judicial philosophy. ${ }^{52}$

Certainly, Rule 10 terms are broad and this gives justices a good share of discretion when evaluating certiorari matters. However, there has been a growing perception among justices over time that many cases decided by the Supreme Court actually did not deserve to be heard. They should just end at the appeal level.

Over time, there has been a claim that a decision by the Supreme Court should be given when an overarching motive is present, stressing its power to rule on issues of large legal or policital significance and to supervise the federal courts. This would assert it as an actual Constitutional Court.

\section{REFERENCES}

ALBERT, Richard; NIKOLAYEVA, Anna. Judicial review of administrative action in the United States. A\&C - Revista de Direito Administrativo \& Constitucional, Belo Horizonte, ano 17, n. 70, p. 1323, out./dez. 2017.

ARAÚJO, Luiz Fernando Diniz. O ativismo judicial e constrangimentos a posteriori. Revista de Investigações Constitucionais, Curitiba, vol. 5, n. 1, p. 129-150, jan./abr. 2018.

ARAÚJO, Luiz Henrique Diniz. Filtros de acesso às Cortes Constitucionais: a Questão Prioritária de Constitucionalidade e os filtros de acesso ao Conselho Constitucional Francês. Revista de Investigações Constitucionais, Curitiba, vol. 6, n. 2, p. 405-422, maio/ago. 2019.

50 EPPS, Daniel; ORTMAN, William. The Lottery Docket. Michigan Law Review. Ann Arbor/MI, vol. 116, p. 705757, march 2018, p. 716.

51 EPPS, Daniel; ORTMAN, William. The Lottery Docket. Michigan Law Review. Ann Arbor/MI, vol. 116, p. 705757, march 2018, p. 716-717.

52 EPPS, Daniel; ORTMAN, William. The Lottery Docket. Michigan Law Review. Ann Arbor/MI, vol. 116, p. 705757, march 2018, p. 716-717 
BRENNER, Saul. Granting certiorari by the united states supreme court: An overview of the social science studies. Law Library Journal, Chicago, vol. 92, n. 2, p. 193-202, 2000.

BRENNER, Saul; WHITMEYER, Joseph M.; Harold J. Spaeth. The Outcome-Prediction Strategy in Cases Denied Certiorari by the U.S. Supreme Court. Public Choice, Berlin, vol. 130, n. 1/2, p. 225 237, jan. 2007.

CASAGRANDE, Cássio Luís; TIBÚRCIO, Dalton Robert. Marbury v. Madison: uma decisão política de manter a Corte fora da política. A\&C - Revista de Direito Administrativo \& Constitucional, Belo Horizonte, ano 19, n. 76, p. 199-224, abr./jun. 2019.

COUSO, Javier A.; HUNEEUS, Alexandra; SIEDER, Rachel. Cultures of Legality. Judicialization and Political Activism in Latin America. Cambridge: Cambridge University Press, 2010.

EPPS, Daniel; ORTMAN, William. The Lottery Docket. Michigan Law Review. Ann Arbor/MI, vol. 116, p. 705-757, march 2018.

FARBER, Daniel; SHERRY, Suzanna. Judgement calls: politics and principle in Constitutional Law. New York: Oxford University Press, 2008.

FEINMAN, Jay M. Law 101. $5^{\text {th }}$ edition. New York: Oxford University Press, 2018.

GEORGE, Tracey E.; GUTHRIE, Chris. Remaking the United States Supreme Court in the Courts' of Appeals Image. Duke Law Journal, Durham/NC, vol. 58, n. 7, Special Symposium Issue: Measuring Judges and Justice, p. 1439-1475, april 2009.

HARTNETT, Edward A. Questioning Certiorari: Some Reflections Seventy-Five Years after the Judges' Bill Source. Columbia Law Review, New York, vol. 100, n. 7, p. 1643-1738, nov. 2000.

JORDÃO, Eduardo. Globalization and convergence in judicial review: what can we learn from the case of Brazil? A\&C - Revista de Direito Administrativo \& Constitucional, Belo Horizonte, ano 17, n. 69, p. 23-31, jul./set. 2017.

KAPISZEWSKI, Diana; SILVERSTEIN, Gordon; KAGAN, Robert A. Consequential Courts. Judicial Roles in Global Perspective. Cambridge: Cambridge University Press, 2013.

LOURENÇO, Cristina Sílvia Alves; GUEDES, Maurício Sullivan Balhe. O STF e o ensino religioso em escolas públicas: pluralismo educacional, laicidade estatal e autonomia individual. Revista de Investigações Constitucionais, Curitiba, vol. 4, n. 3. p. 145-165, set./dez. 2017.

MACHADO, Marta Rodriguez de Assis; COOK, Rebecca J. Constitutionalizing abortion in Brazil. Revista de Investigações Constitucionais, Curitiba, vol. 5, n. 3, p. 185-231, set./dez. 2018.

MORAWA, Alexander H. E. Ceriorari and the Political Judge: Discretionary Case Selection by the United States Supreme Court and the European Court of Human Rights Compared. The University of Tasmania Law Review, Hobart, Tasmania, vol. 33, n. 2, p. 222-234, 2014. 
NARECHENIA, Tejas N. Certiorari, Universality, and a Patent Puzzle. Michigan Law Review, Ann Arbor, vol. 116, p. 1345-1407, june 2018.

SCOTT, Kevin M. Shaping the Supreme Court's Federal Certiorari Docket. Justice System Journal, Williamsburg, vol. 27:2, p. 191-207, 2006.

TANG, Aaron. The Ethics of Opposing Certiorari Before the Supreme Court. Harvard Journal of Law and Public Policy, Cambridge/MA, vol. 35, n. 3, p. 933-990, summer 2012.

THOMPSON, David C.; WACHTELL, Melanie F. An Empirical Analysis of Supreme Court Certiorari Petition Procedures: The Call for Response and the Call for the Views of the Solicitor General, Geo. Mason L. Rev., Arlington, vol. 16, p. 237-302, 2009.

UNITED STATES OF AMERICA. Rules of the Supreme Court of the United States. Rule 10 - Considerations Governing Review on Certiorari. Available at https://law.justia.com/codes/us/1997/ title28/app/rulesofth/rule10/. Retrieved May 4, 2020 